\title{
SOLID-STATE PHYSICS AT MELBOURNE
}

\begin{abstract}
A SUMMARY of the proceedings and notes on the papers presented to the conference on solid. state physics held in Melbourne during August 17-21, 1959, under the auspices of the Australian branch of the Institute of Physics, has been published in the British Journal of Applied Physics (11, $137 ; 1960)$. The conference was the first of its kind to be held in Australia, and there was an attendance of about 130 . Financial assistance in the form of grants was received from the Australian Atomic Energy Commission, the Commonwealth Scientific and Industrial Research Organization, the Australian Academy of Science, the Universities of Melbourne and New South Wales, and several industrial concerns. Forty-six papers were read and discussed at the conference, and the texts of a number of the original contributions have now been published in a special issue of the Austratian Journal of Physics (13, No. 2A; July 1960).

Prof. C. S. Barrett, of the University of Chicago, discusses the structure of the semi-metal bismuth at low temperatures, and describes a precision determination as a function of temperature of the displace-
\end{abstract}

ment parameter of zone-refined bismuth containing less than $0 \cdot 3$ part per million of spectroscopically detectable impurity. The small but significant dependence on temperature at low temperatures disagrees with predictions from Blount and Cohen's theory and may signify a decrease in resistance to atom displacement from the simple cubic structure because of the thermal expansion of the structure.

Dr. J. J. Gilman, of the General Electric Research Laboratory, contributes an interesting paper in which he presents evidence to show that crystals exhibit a plastic resistance to dislocation motion. Direct observation of such resistance has been made with lithium fluoride and ferrosilicate erystals. The yield stresses and indentation hardnesses of many crystals can be correlated with their elastic moduli, and therefore the elastic modulus is one important factor which determines the plastic resistance. Another is the crystal structure type. Several papers deal with thermal transport in alloys, and individual papers with the nucleation and growth of ice crystals on crystalline substrates, X-ray measurements in metals, and the photographic process as a diatomic reaction.

\section{SCIENTIFIC RESEARCH IN BELGIUM}

\begin{abstract}
$\mathrm{T}$ HE annual report for 1959 of the Institute for the Encouragement of Scientific Research in Industry and Agriculture, Brussels, records research grants totalling $192,507,902$ francs and grants amounting to a further $7,128,750$ francs for special courses and travel; 65 of the 79 grants for special courses were in chemical seiences and 7 in agricultural science*.

Of the research grants, one of $19,945,000$ francs was for a systematic investigation of the pedological character of Belgian soils, and the completion of the pedological map of the country; 13,220,000 francs were for the continuation of researches on the physics of the solid state in the laboratories of Prof. Dekeyser at the University of Ghent, of the Electrical Construction Factory at Charleroi, of Prof. Brasseur at the University of Liège and of the Gevaert Factory; $11,200,000$ francs to the Scientific and Technical Research Centre of the Metal Industry for research on the metallurgy of steel and special ferrous alloys, and a further $1,825,000$ francs for soldering research; $3,900,000$ francs to the Carbochemical Society of Tertre for research on textile dyeing; and 6,750,000 francs to the Gevaert Photoproducts Society for work on photographic dyes and processes of colour photography.

The Committee for the Application of Isotopical Methods in Agronomic Research received 9,485,000 francs for the continuation of researches on the utilization of radioisotopes, the Hainault Section of the National Centre for Metallurgical Research 7,770,000 francs for investigations on furnaces, $4,865,000$ francs

* Institut pour l'Encouragement de la Recherche Scientiflque dans l'Industrie et 1'Agriculture. Rapport Annuel. Exercise 1959. Pp. 237. (Bruxelles: Institut pour l'Encouragement de la Recherche Scientifique dans l'Industrie et l'Agriculture, 1960.)
\end{abstract}

for its work on the continuous fusion of steel, the resistance of steel to brittle fracture, the improvement of converters, etc.; and the General Metallurgical Society of Hoboken 7,560,000 francs for work on tantalum, niobium and their conversion to massive metal. Further subsidies of $2,905,000$ francs and $4,455,000$ francs went to the National Centre of Metallurgical Research and the Scientific and Technical Research Centre of the Metal Industry, respectively, for continuation of research on the mechanical properties of steel and improved methods of utilizing steel. The Liège Section of the former received a further 6,891,500 francs covering Belgian participa. tion in the work of the International Committee for Research on Low Temperature Furnaces and 6,200,000 francs for continuation of research on cobalt. The Committee for the Study of the Nitrogen Problem received $6,520,000$ francs for its studies on nitrogen in Belgian soils and on the fixation of nitrogen by legumes; the Centre for the Biological and Colloidal Chemistry of the Soil, 6,395,000 franes for work on the formation of the organic matter of the soil and on the soil colloids; the Research Centre of Gorsem, 5,500,000 franes for its researches on horticultural and agricultural diseases and pests; the Scientific and Technical Centre of Belgian Textile Industry, 5,109,500 francs for new research on the manufacture of fibroplasts, on the carding of wool, on the utilization of isotopes for investigating the spinning of cotton and on the inter-relation between the properties of the threads and fibres of cotton; the Biological Forestry Centre of Campine limbourgeoise, 4,800,000 franes for pedological, entomological, genetic and sylvicultural research bearing on the improvement of exploitation, conservation and 
natural regeneration of forests; and the Agricultural Physicochemical Centre, 3,960,000 francs for work on an improved mothod for the chemical determination of the nutritive elements in soil and the interpretation of the analytical results.

Grants of $3,155,000$ francs and 2,670,000 francs went to the Scientific and Technical Research Centre of the Explosives Industry and the Centre for Research on Plant Hormones, respectively ; 2,630,000 francs to the Centre for Research on Parasite Diseases of Domestic Animals; 2,400,000 franes to the National Committee for the Study of Fruit Cultivation for the equipment of two large conditioning chambers; 2,365,000 francs to the Centre for the Study of the Forest Soils of Ardenne and of Gaume for research on types of forest humus, and 2,240,000 francs to the Centre for Research on Diseases of Ornamental Plants. The Committee for the Study of Agriculture received a grant of 1,975,000 francs; the Plant Physiology Laboratory of the
Gorsem Research Centre, 1,890,000 francs to extend its researches on the maturation of fruits and their conservation and studies on photosynthesis and on the influence of insecticides and fungicides on the physiology of the vegetables on which they are used ; the Centre for Phytopharmaceutical Research, $1,836,000$ francs for research on the utilization of phytopharmaceutical products ; and the Committee for the Study of the Solid State, 1,650,000 francs for research on the production of durable magnetic materials.

Among other grants are 1,610,000 francs to the Pedological Service of Belgium, 1,412,000 francs to the Technical and Scientific Centre of the Wood Utilization Industry, 1,410,000 franes to the Committee for Strawberry Research, $1,350,000$ francs to the Com. rnittee for the Study of Creep of Metals, 1,230,000 francs to the Belgian Centre for the Study of Corrosion "Cebelcor" and $1,080,000$ francs to the Committee for the Scientific Study of Lactation.

\section{MYOCARDIAL TISSUE CHANGES ASSOCIATED WITH RIGOR MORTIS}

NITIAL tissue changes associated with rigor 1 mortis do not appear simultaneously throughout the myocardium, their onset being earlier in some areas than in others; such changes result from biochemical modifications occurring after death in myocardial fibres, that is, post-mortem dephosphorylation of adenosine triphosphate and disappearance of creatine phosphate. The evidence from an investi. gation by Piero Gallo, of the Tumour Control Research Centre, Rome, indicates that the adenosine triphosphate and creatine phosphate content in the areas first involved by rigor mortis is significantly smaller than that found to be present in other tissue areas (Cardiologia 37 Supp. 1; 1960). Since adenosine triphosphate and creatine phosphate represent the last link in the long chain of reactions involved in the production of chemical energy, the results enable the rate of this metabolic stage in different tissue areas to be evaluated quantitatively.

Far from being uniform throughout, the rate of energy production appears to be lower in areas where microscopic signs of rigor mortis begin, because these areas have the lowest content of adenosine triphosphate and creatine phosphate; the areas first involved by rigor mortis are segments averaging $20 \mu$ in length of cardiac muscle fibres, the whole width of which is affected.

The non-uniform distribution of adenosine triphosphate and creatine phosphate in the myocardium has been compared with the results of investigations concerning $(a)$ the distribution of interfibrillar cyto chondria, which is remarkably uniform; and $(b)$ the diffusion speed of oxygen and energetic materials from the capillaries to the fibres, which varies in tissue areas.

These variations chiefly affect the aerobic phase of metabolism as well as the concentration of creatine phosphate and adenosine triphosphate, which is lower in more slowly oxygenated areas.

Analysis of these experimental findings enables the following conclusion to be drawn: the relatively small amount of adenosine triphosphate in some myocardial areas is not dependent on the distribution of cytochondria, but appears to be due to the fact that such areas are supplied with oxygen at a slower rate than the remaining tissue areas. The slow rate of gas exchanges in such areas seems to be responsible for a marked decrease in the yield of oxidative phosphorylation processes, so ensuring the transfer of chemical energy derived from breakdown and oxidation of energetic materials to creatine phosphate and adenosine triphosphate, which retain it and yield it to myocardial fibrils at the time of contraction.

In the rabbit, topical application of $\gamma$-hexane on the skin at a dose-level of $\mathbf{2} \mathrm{mgm}$./kgm. body-weight does not alter the course of myocardial tissue changes associated with rigor mortis, which exhibit a pattern almost identical to that observed in animals not treated with this insecticide.

\section{BOWER-BIRDS}

$\mathrm{T}$ HE popular belief that the display of bowerbirds is either indiscriminate or satisfies some conscious æstheticism has been questioned by Prof. A. J. Marshall, of Monash University (Endeavour, 19, No. 76 ; October 1960). He suggests that, remarkable as they are, the bowers and display paraphernalia of bower-birds are no more than an extension of the territorial and display impulses to be found in other birds. Avian display - visual and auditory-is usually associated with conflict and the establishment of territorial domination, pair formation, and seasonal gonad development; final synchronization of the sexual processes of the pair occurs when the environment changes seasonally to a state appropriate for successful reproduction. Only then will the female accept the male. All kinds of widely unrelated birds - for example, waders, grouse, manakins and lyrebirds-make simple display-grounds and posture on 